NBER WORKING PAPER SERIES

\title{
STOCK RETURNS AND EXPECTED BUSINESS CONDITIONS: HALF A CENTURY OF DIRECT EVIDENCE
}

\author{
Sean D. Campbell \\ Francis X. Diebold \\ Working Paper 11736 \\ http://www.nber.org/papers/w11736 \\ NATIONAL BUREAU OF ECONOMIC RESEARCH \\ 1050 Massachusetts Avenue \\ Cambridge, MA 02138 \\ November 2005
}

For support we thank the Humboldt Foundation, the Guggenheim Foundation, the National Science Foundation, and the Wharton Financial Institutions Center. For helpful conversations we thank seminar participants at the Board of Governors of the Federal Reserve System and the Swiss National Bank (Study Center Gerzensee), as well as Andrew Ang, Ravi Bansal, Hui Guo, Martin Lettau, Sydney Ludvigson, Josh Rosenberg, Steve Sharpe, Jessica Wachter, and Kamil Yilmaz. None of those thanked, however, are responsible for the outcome. The views expressed herein are those of the author(s) and do not necessarily reflect the views of the National Bureau of Economic Research.

(O2005 by Sean D. Campbell and Francis X. Diebold. All rights reserved. Short sections of text, not to exceed two paragraphs, may be quoted without explicit permission provided that full credit, including $\odot$ notice, is given to the source. 
Stock Returns and Expected Business Conditions: Half a Century of Direct Evidence

Sean D. Campbell and Francis X. Diebold

NBER Working Paper No. 11736

November 2005

JEL No. G12

\begin{abstract}
We explore the macro/finance interface in the context of equity markets. In particular, using half a century of Livingston expected business conditions data we characterize directly the impact of expected business conditions on expected excess stock returns. Expected business conditions consistently affect expected excess returns in a statistically and economically significant countercyclical fashion: depressed expected business conditions are associated with high expected excess returns. Moreover, inclusion of expected business conditions in otherwisestandard predictive return regressions substantially reduces the explanatory power of the conventional financial predictors, including the dividend yield, default premium, and term premium, while simultaneously increasing R-squared. Expected business conditions retain predictive power even after controlling for an important and recently introduced non-financial predictor, the generalized consumption/wealth ratio, which accords with the view that expected business conditions play a role in asset pricing different from and complementary to that of the consumption/wealth ratio. We argue that time-varying expected business conditions likely capture time-varying risk, while time-varying consumption/wealth may capture time-varying risk aversion.
\end{abstract}

Sean D. Campbell

Federal Reserve Board

Francis X. Diebold

Department of Economics

University of Pennsylvania

3718 Locust Walk

Philadelphia, PA 19104-6297

and NBER

fdiebold@sas.upenn.edu 
“... [if] cyclical variation in the market risk premium is present, ...we would expect to find evidence of it from forecasting regressions of excess returns on macroeconomic variables over business cycle horizons. Yet the most widely investigated predictive variables have not been macroeconomic variables, but financial indicators."

(Lettau and Ludvigson, 2005)

\section{Introduction}

The equity market macro-finance interface presents a clear puzzle: Many have argued that business conditions should be linked to expected excess returns (e.g., Fama and French, 1989, 1990; Chen, Roll and Ross, 1986; Barro, 1990 ), yet the standard predictors are not macroeconomic, but rather financial: dividend yields, default premia, and term premia. Several authors have claimed that the standard financial predictors may serve as proxies for expected business conditions, and they interpret their predictive power through that lens. ${ }^{1}$ In the absence of direct expectations data, however, the claim that expected excess equity returns are driven by expected business conditions remains largely speculative.

Against this background, we use a well-known survey to provide direct evidence on the links between expected business conditions and expected excess equity returns over some fifty years. We ask two key sets of questions. First, are the standard financial predictors related to expected business conditions, and if so, how?

Second, do expected business conditions indeed forecast future returns? Are expected business conditions a useful predictor of excess returns even after controlling for the standard financial predictors? And conversely, are the standard financial predictors useful even after controlling for expected business conditions? If not, do any standard financial predictors retain power after conditioning on expected business conditions?

${ }^{1}$ See, among many others, Campbell and Shiller (1988), Fama and French (1988, 1989), Ferson and Harvey (1991), Campbell (1991) and Lettau and Ludvigson (2005). 
We proceed as follows. In section 2 we describe the data, and in particular our surveybased measure of expected business conditions. In section 3 we examine the links between expected business conditions and the standard financial predictors of excess returns. In section 4 we document the effects of including expected business conditions in otherwise-standard return predictive regressions, at both short and long horizons, and we also examine a recentlyintroduced predictor, the consumption/wealth ratio, which turns out to be very important. We conclude in section 5 .

\section{Data}

Here we introduce the data on which our analysis is based, with special attention paid to the Livingston survey, and we briefly document some of their properties.

\section{Excess Returns and Financial Predictors}

We construct excess stock returns using the CRSP value-weighted portfolio and the 90day U.S. Treasury bill rate, 1952:1-2003:2. We examine several standard and widely-studied financial return predictors, the dividend yield ( $D P$, calculated for the CRSP value-weighted portfolio), the default premium ( $D E F$, calculated as the yield difference between a broad corporate bond portfolio and the Aaa yield) and the term premium (TERM, calculated as the yield difference between a ten-year Treasury bond and a one-month Treasury bill), also 1952:12003:2. In Table 1, we present summary statistics for excess returns and all predictors. The Livingston Forecasts

Our business conditions expectations data come from the Livingston Survey of Professional Forecasters. The Livingston survey is widely followed, heavily studied, and 
generally respected. ${ }^{2}$ Moreover, and importantly, it is available over a long sample period, in contrast for example to the Survey of Professional Forecasters, which begins only in $1968 .^{3}$ The Livingston survey is semi-annual, conducted in June and December. Our sample begins in 1952:1, which matches the beginning of the continuously-recorded Livingston survey data, and continues until 2003:2. ${ }^{4}$

We construct real GDP growth expectations from the nominal GDP and CPI level expectations reported in the Livingston survey, which solicits respondents' views regarding economic variables in six and twelve months' time. ${ }^{5}$ We aggregate the Livingston responses into median forecasts, obtaining, for each series and survey date, a median forecast of the series' level six and twelve months hence, and we take log differences to obtain an approximate twostep-ahead growth rate forecast, as in Gultekin (1983). ${ }^{6}$ The final result is a series of two-stepahead real GDP growth forecasts, $E_{t} g_{t+1, t+2}, t=1952: 1-2003: 2$.

The two-step-ahead real growth rate forecasts constructed from the Livingston data appear well-behaved. In Figure 1 we show the actual growth rates, the Livingston forecasts, and (1997).

${ }^{2}$ For a fine overview of the history and use of the Livingston survey, see Croushore

${ }^{3}$ It would be interesting, but beyond the scope of this paper, to attempt to replicate its results using expectations from the Survey of Professional Forecasters.

${ }^{4}$ Note the timing convention associated with our use of semi-annual data: 2001:2, for example, refers to the second half of 2001, i.e., 7/1/2001 through 12/31/2001.

${ }^{5}$ Unfortunately, the Livingston survey does not ask participants about expectations of current GDP of CPI levels, so we can not use it to construct one-step-ahead forecasts (a step being a six-month interval).

${ }^{6}$ Presumably one could also make some use of the distribution of forecasts, but we have not yet explored that avenue. See Miller (1977) and Guo and Savickas (2005). 
the corresponding forecast errors. The forecasts move with the actual growth rates but are smoother, which is a well-known property of optimal forecasts of stationary series. ${ }^{7}$ Moreover, $^{-}$ the forecast errors appear to have zero mean and display no obvious predictable patterns. ${ }^{8}$ The sharp cutoff in the sample autocorrelation function of the forecast errors beyond displacement one, as shown in Figure 2, indicates first-order moving average structure, which is consistent with optimality of the two-step-ahead forecasts. The mean Livingston (annualized) real GDP growth rate forecast in Table 1 is 2.54 percent, which closely accords with historical growth realizations.

Ultimately, however, the issue of whether the Livingston forecasts are fully optimal is of limited relevance for our purposes. They simply are what they are, and we take them at face value, asking whether and how they are linked to expected excess equity returns. The first step of that inquiry involves characterizing the links between the Livingston expectations and the standard financial excess return predictors, to which we now turn.

\section{Expected Business Conditions and Financial Predictors of Excess Returns}

In their classic assessment of the predictability of excess stock returns, Fama and French (1989) find that excess returns are indeed predictable, with most predictive power coming from the dividend yield, the default premium, and the term premium. More precisely, they estimate regressions of the form

$$
R_{t, t+h}=\beta_{0}+\beta_{1} D P_{t}+\beta_{2} T_{E R M_{t}}+\beta_{3} D E F_{t}+\varepsilon_{t, t+h},
$$

${ }^{7}$ See Diebold (2004).

${ }^{8}$ Moreover, even if the errors did have a non-zero mean, they would not necessarily be suboptimal, because biased forecasts are optimal under asymmetric loss. See Leitch and Tanner (1991) and Christoffersen and Diebold (1997). 
and they document a strong relationship in terms of the usual $t$-statistics, $R^{2}$ values, and so forth, where $R_{t, t+h}$ is the excess return on a broad stock portfolio over $h$ periods, for $h$ ranging from one quarter to several years.

The key open question is why financial variables should predict excess returns. Fama and French (1989) suggest that the predictive power may derive from correlation with expected business (macroeconomic) conditions. Notoriously little direct evidence exists, however, as to whether the financial variables actually are linked to expected business conditions. In this section we provide precisely such direct evidence, examining the extent to which the Livingston real growth expectations are linked to the standard financial predictors, both pairwise and jointly. We estimate regressions of Livingston expected business conditions $E_{t} g_{t+1, t+2}$ on the dividend yield $D P_{t}$, the default premium $D E F_{t}$, and the term premium $T E R M_{t}$. In Table 2 we show results from both simple and multiple regressions.

First consider the simple regressions, which reveal some links between the financial variables and expected business conditions, although the strength and statistical significance vary across variables and specifications. First, the dividend yield is negatively related to expected business conditions. This accords with the dividend discount model, which predicts that the dividend yield should fall when necessary to offset higher expected growth in dividends. ${ }^{9}$ Second, the term premium is positively related to expected business conditions. This accords with the basic notion that the yield curve slope is a leading indicator, with inverted

${ }^{9}$ That is, the dividend yield, $D_{t} / P_{t}$, is equal to the difference between the required rate of return and the growth rate of dividends, $r-g$. Hence an increase in $g$ will reduce $D_{t} / P_{t}$, other things equal. 
yield curves indicating a likely future recession, due for example to tightening of monetary policy, which increases short rates. Finally, the default premium appears positively associated with expected business conditions. This seemingly anomalous result may be due to the short horizons associated with the Livingston forecasts; that is, notwithstanding the positive correlation between default premia and expected business conditions at short horizons, default premia may be negatively correlated with expected business conditions at longer horizons of, say, two or three years.

Now consider the multiple regressions, which provide a summary distillation of the links between expected real business conditions and the financial variables, taken jointly as a set. The results show that expected business conditions are indeed systematically linked to the financial variables, with $R^{2} \mathrm{~s}$ of nearly thirty percent. This is particularly noteworthy given the short horizons of the Livingston expectations, because the dividend yield and term premium variables - in addition to the default premium as already discussed - are often thought to have maximal predictive value at much longer horizons.

In summary, the results of this section help us to understand why the standard financial variables "work" in predictive regressions for excess stock returns: they are correlated with expected business conditions, as conjectured by Fama and French (1989). Crucially, however, the correlation is far from perfect $\left(R^{2} \approx 0.3\right)$. That is, the financial variables, even when taken jointly as a set, provide only highly noisy proxies of expected business conditions. This suggests that, to the extent that expected excess returns are driven by expected business conditions, superior return predictions may be produced via a direct measure of expected business conditions. We now provide precisely such a direct assessment of the effects of expected 
business conditions on expected excess stock returns.

\section{Expected Business Conditions and Expected Excess Returns}

We now consider the central question of whether and how expected business conditions are linked to expected excess returns. We extend the approach of Fama and French (1989) to include the Livingston expected business conditions as a predictor, estimating regressions of the form

$$
R_{t+1, t+2}=\beta_{0}+\beta_{1} E_{t} g_{t+1, t+2}+\beta_{2} D P_{t}+\beta_{3} T E R M_{t}+\beta_{4} D E F_{t}+\varepsilon_{t+1, t+2},
$$

where the timing of the excess return $R_{t+1, t+2}$ matches that of expected business conditions $E_{t} g_{t+1, t+2}$, and where we standardize all predictors to facilitate comparison of coefficient magnitudes.

Note that the predictive regression (2) involves a two-step-ahead forecast rather than the one-step-ahead forecast commonly employed in the literature. We focus on two-step-ahead forecasts for two reasons. First, there is some uncertainty as to the precise time when the growth forecasts are made, because they are constructed from surveys, and some forecasts may in fact be made after the end of June or December, resulting in an overlap in the information sets from which $E_{t} g_{t+1, t+2}$ and $R_{t, t+1}$ are derived. Focusing on forecasts of $R_{t+1, t+2}$ rather than $R_{t, t+1}$ guards against this possibility. Second, and most importantly and obviously, pairing $R_{t+1, t+2}$ with $E_{t} g_{t+1, t+2}$ matches the timing of the excess return to the horizon of the growth forecast.

\section{$\underline{\text { Basic Results }}$}

We show the results in Table 3. First consider the simple regressions in the upper panel, in which we include the various predictors one at a time, and consider in particular the results for expected business conditions. The point estimate indicates an economically important negative 
relationship between expected excess returns and expected business conditions, with a one standard deviation decrease in $E_{t} g_{t+1, t+2}$ producing roughly a 0.2 standard deviation increase in expected excess returns. The relationship is highly statistically significant at any conventional level, and the $R^{2}$ is quite high (for the return-prediction literature) at 4.74 percent.

The simple regression results for the standard financial predictors, $D P_{t}, T E R M_{t}$, and $D E F_{t}$, are comparatively lackluster. The coefficient point estimates for the financial predictors are all smaller than that for $E_{t} g_{t+1, t+2}$; indeed, those for $T E R M_{t}$, and $D E F_{t}$ are less than half that of $E_{t} g_{t+1, t+2}$. Similarly, the significance levels for the conventional predictors are weaker than that for $E_{t} g_{t+1, t+2}$, and $T E R M_{t}$ and $D E F_{t}$ are statistically insignificant at any conventional level. Finally, the $R^{2}$ values for the conventional predictors are all smaller than that for $E_{t} g_{t+1, t+2}$, and those for $T E R M_{t}$ and $D E F_{t}$ are negligible.

Now consider the multiple regression results reported in the lower panel of Table 3. Regression of excess returns on the three standard financial predictors yields an $R^{2}$ of 6.28. The size, significance, and negative sign of the coefficient on growth expectations from the multiple regression match that of the earlier-discussed simple regression. The multiple regression also makes clear that the key financial predictor, whether based on coefficient size or significance, is dividend yield. Crucially, however, introduction of growth expectations as a predictor reduces both the dividend yield coefficient point estimate and its t-statistic by roughly one third, while simultaneously raising the $R^{2}$ by more than fifty percent.

All told, the results of our generalized Fama-French analysis clearly point to expected business conditions as a key determinant of expected excess returns, and moreover, they support our earlier argument that the standard financial predictors are largely proxies for expected 
business conditions: Once expected business conditions are included, the contribution of the standard financial predictors is sharply reduced, if not completely eliminated.

\section{Including the Consumption/Wealth Ratio}

In recent years $C A Y$, the generalized $(\log )$ consumption-wealth ratio of Lettau and Ludvigson (2001a, b), has received attention as a predictor of excess returns. ${ }^{10} C A Y$ is partly non-financial insofar as it is driven partly by consumption, and partly financial insofar as nonhuman wealth depends partly on equity holdings. Here we assess its marginal predictive content relative to the standard financial predictors and expected business conditions.

First consider the correlation between expected business conditions and the consumption/wealth ratio. We showed in section 3 that expected business conditions are correlated with the standard financial predictors, which emerge as (noisy) proxies for expected business conditions. The question immediately arises as to whether the consumption/wealth ratio is just another noisy proxy for expected business conditions.

As reported in Table 2, the coefficients from simple regressions of $E_{t} g_{t+1, t+2}$ on $C A Y_{t}$ are small and insignificant, and the associated $R^{2}$ values are small. In addition, multiple regressions of $E_{t} g_{t+1, t+2}$ on $C A Y_{t}$ and the standard financial predictors produce insignificant $C A Y_{t}$ coefficients. Overall, then, both the simple and multiple regression analyses suggest that the relationship between $E_{t} g_{t+1, t+2}$ and $C A Y_{t}$ is likely non-existent, and at any rate certainly much weaker than the relationship between $E_{t} g_{t+1, t+2}$ and the standard financial predictors. Hence, although the financial predictors appear to proxy for expected business conditions, the

${ }^{10} C A Y$ is the residual from a regression of $\log$ consumption on $\log$ human wealth (labor income) and $\log$ non-human wealth (assets). 
consumption/wealth ratio appears to capture something else. ${ }^{11}$

Now consider predictive regressions for excess returns, beginning with the simple regression of $R_{t+1, t+2}$ on $C A Y_{t}$ reported in Table 3. Interestingly, the regression coefficient is large, the significance level is high, and the $R^{2}$ is high. Indeed, the $C A Y$ regression produces the largest absolute coefficient, the highest marginal significance level, and the highest $R^{2}$ of any simple predictive regression. These results essentially confirm the findings of Lettau and Ludvigson (2001b), using a different sample and semi-annual rather than quarterly returns.

The predictive multiple regressions reported in Table 3 reveal equally interesting patterns. First, including $C A Y$ in the standard regression on financial predictors reveals a strong and significant role for $C A Y$ in predicting excess returns, increasing the $R^{2}$ by more than thirty percent. Interestingly, inclusion of $C A Y$ along with the traditional financial predictors results in a slightly smaller increase in predictive content than does inclusion of $E_{t} g_{t+1, t+2}\left(R^{2}=8.56\right.$ vs. $\left.R^{2}=9.41\right)$.

Second, inclusion of both $C A Y$ and expected business conditions in the standard regression on financial predictors renders the financial predictors irrelevant, leaving just $C A Y_{t}$ and $E_{t} g_{t+1, t+2}$. Interestingly, the consumption wealth ratio and expected business conditions alone have more predictive content for excess returns than do all three financial predictors. In particular, the specification including only $C A Y$ and $E_{t} g_{t+1, t+2}$ has an $R^{2}$ more than 50 percent larger than the $R^{2}$ from the specification including only the traditional financial predictors. All told, it seems clear that $E_{t} g_{t+1, t+2}$ and $C A Y_{t}$ play important and complementary roles in

${ }^{11}$ This result corroborates Lettau and Ludvigson (2001b), who find that $C A Y$ has no predictive power for non-financial macro variables such as aggregate labor income or consumption. 
determining expected excess returns, whereas the financial predictors largely "work" because of their links to $E_{t} g_{t+1, t+2}$ and/or $C A Y$.

Finally, in discussing the results in Table 3 it is noteworthy that, even in the presence of $C A Y$, expected business conditions continue to exhibit a strong and statistically significant effect on future excess returns. Lettau and Ludvigson (2001b, 2005) have previously shown that a large array of excess return predictors are rendered impotent when jointly analyzed alongside the consumption wealth ratio. The results in Table 3 indicate that the predictive content of expected business conditions is robust to and largely independent from the inclusion of the consumption wealth ratio. These findings suggest that the channel through which expected business conditions affect expected returns is distinct from the channel through which the consumption wealth ratio operates.

\section{$\underline{\text { Long-Horizon Analysis }}$}

The results thus far provide clear evidence that expected business conditions help to forecast excess returns at a six-month horizon. Here we examine the value of expected business conditions in forecasting excess returns at various longer horizons. We measure the longhorizon regression coefficients using Hodrick's (1992) unified vector autoregression (VAR) methodology, which produces predictive regression coefficients and other model diagnostics at all horizons from a single underlying VAR.

In Table 4 we report long-horizon regression statistics for horizons ranging from six to sixty months. As before, we standardize each predictor, so that we can compare the imputed long-horizon regression coefficients across predictors. In the top and bottom panels of Table 4 we present long-horizon multiple regression statistics implied by the Hodrick VAR system, 
excluding and including expected business conditions, respectively. Each panel contains multiple regression coefficients for each forecasting horizon and the implied $R^{2} \cdot{ }^{12}$

The patterns in the multiple regression coefficients indicate that the effect of including expected business conditions dissipates as the forecasting horizon lengthens. This is most evident when looking at the dividend yield coefficient. Inclusion of expected business conditions reduces the dividend yield coefficient by 33 percent at the six month horizon, whereas it reduces it by only five percent at the sixty month horizon. A similar pattern arises for the long-horizon $R^{2} \mathrm{~s}$. At the six month horizon, adding expected business conditions to the set of predictors increases the $R^{2}$ by roughly 32 percent. At horizons beyond eighteen months, including expected business conditions results in no appreciable increase in return predictability.

The general pattern in coefficients and predictability at horizons beyond six months indicates that expected business conditions are most useful for predicting excess returns over the six to eighteen month horizon. This finding is appealing. It is consistent with both the short to medium term nature of the Livingston forecasts, and with the possibility that other predictors contain information, not contained in the Livingston forecasts, of relevance for forecasting longer-term excess returns. Quite naturally, then, the information content of the Livingston forecasts appears most relevant over the horizons to which they are tailored.

Expected Business Conditions and Stock Market Volatility ${ }^{13}$

We have shown that expected business conditions forecast excess stock returns at short

${ }^{12}$ In Tables 6 and 7 we provide estimates of the "Hodrick VARs" and associated residual covariance matrices from which we produce the results of Table 4.

${ }^{13}$ We thank Sydney Ludvigson for encouraging us to perform the analysis reported in this sub-section. 
and medium horizons. Here we examine a possible reason why expected business conditions forecast stock returns: expected business conditions may forecast future volatility and hence may be linked to perceived systematic risk and expected excess returns.

The claim that business conditions are linked to stock market volatility is certainly not new. In particular, as persuasively documented in an extensive study by Schwert (1989) and echoed in subsequent work by Hamilton and Lin (1996) using very different and complementary methods, stock market risk increases in recessions. Indeed, it is fair to say that business conditions are the only important and robust covariate of stock market volatility identified thus far, notwithstanding the many investigations.

In Table 5 we examine the link between expected business conditions and realized stock market volatility. We use two data sources to compute realized semi-annual stock return volatility. The first is the daily CRSP value-weighted index, which is available since 1963, resulting in a sample from 1963:1 through 2003:2. The second is the daily S\&P 500 index, which is available since 1951, resulting in a sample from 1951:2 through 2003:2. Then we regress realized volatility, $\sigma_{t+1, t+2}$, on expected business conditions, $E_{t}\left(g_{t+1, t+2}\right)$, and the other predictors considered earlier.

Consider first the regression results for CRSP-based realized volatility in the top panel. The univariate results indicate that expected business conditions, the dividend yield, and CAY have highly statistically significant predictive ability for future volatility. The estimated relationship between expected business conditions and future volatility, in particular, agrees with the findings of previous research: low growth expectations forecast high stock return volatility. Moreover, when the predictors are considered jointly in a multiple regression, expected business 
conditions emerge as the most highly significant predictor of volatility, with a t-statistic in excess of 4.0. As in the univariate case, low growth expectations presage high future volatility. Now consider the results for S\&P-based realized volatility in the bottom panel of Table 5. The signs of the univariate coefficient estimates match those of the CRSP-based estimates in the top panel, although the magnitudes of the univariate estimates are generally smaller for the longer S\&P-based sample. The multiple regression results, however, are considerably more uniform across the two samples. In particular, the estimated coefficient for expected business conditions changes only slightly from -0.42 in the top CRSP-based panel to -0.36 in the bottom S\&P-based panel, and in each case t-statistic exceeds 3.0. The estimated coefficients for the remaining predictors are also very similar in terms of sign, magnitude and statistical significance across the top and bottom panels, indicating that the relationship between stock return volatility and the predictors is robust to changes in the sample period and the index used to construct the volatility measure.

\section{Concluding Remarks}

We found two key excess return predictors, Livingston business conditions expectations and Lettau-Ludvigson generalized consumption/wealth. Presumably, however, the timevariation in expected excess returns is ultimately driven by time-varying expected risk and/or time-varying risk aversion. Hence the question naturally arises as to whether and how our predictors are linked to equity market risk and risk aversion.

We believe that the Livingston business conditions expectations likely capture timevarying risk, as we discussed earlier in detail. But what of the Lettau-Ludvigson generalized consumption/wealth ratio, $C A Y$ ? We believe that $C A Y$ likely captures time-varying risk 
aversion, via the following logical chain:

(1) Theoretically, time-variation in expected excess returns is ultimately driven by timevarying expected risk, time-varying risk aversion, or both;

(2) Empirically, time-variation in expected excess returns is driven by two key predictors, expected business conditions and $C A Y$;

(3) Expected business conditions are linked to risk;

(4) Expected business conditions and $C A Y$ are largely unrelated;

(5) Hence, by elimination, $C A Y$ must be linked to risk aversion.

Our assertion that $C A Y$ captures time-varying risk aversion matches that of Lettau and Ludvigson (2001b) and provides a largely independent confirmation of their work, insofar as we arrive at the insight via a very different route. Note, however, that we do not assert that movements in $C A Y$ are exclusively driven by movements in risk aversion. In particular, our volatility forecasting results indicate that movements in $C A Y$ are also related to movements in risk. Accordingly, we suggest that $C A Y$ measures both risk aversion and a risk component unrelated to the risk component forecasted by the Livingston expectations.

Both our results and our interpretation are very much in agreement with the emerging empirical consensus that expected excess returns are counter-cyclical - not only for stocks, as in Lettau and Ludvigson (2001b), but also for bonds, as in Cochrane and Piazzesi (2005). ${ }^{14}$ Interestingly, part of the literature emphasizes higher risk in recessions, as in Constantinides and Duffie (1996), and another part emphasizes higher risk aversion in recessions, as in Campbell

\footnotetext{
${ }^{14}$ See for example Andersen, Bollerslev, Diebold and Wu (2005) and the references therein.
} 
and Cochrane (1999). Our results unify those two literatures, suggesting that the cyclicality of both risk and risk aversion contributes to the counter-cyclicality of expected excess returns: growth expectations are procyclical and have a robust negative impact on expected excess returns, and $C A Y$ is countercyclical and simultaneously has a robust positive impact. 


\section{References}

Andersen, T.G., Bollerslev, T., Diebold, F.X. and Wu, J. (2005), “A Framework for Exploring the Macroeconomic Determinants of Systematic Risk," American Economic Review, 95 (May), 398-404.

Barro, R.J. (1990), “The Stock Market and Investment,” Review of Financial Studies, 3, 115131.

Campbell, J.Y. (1991), “A Variance Decomposition for Stock Returns,” Economic Journal, 101, 157-179.

Campbell, J.Y. and Cochrane, J.H. (1999), "By Force of Habit: A Consumption-Based Explanation of Aggregate Stock Market Behavior,” Journal of Political Economy, 107, 205-251.

Campbell, J.Y. and Shiller, R.J. (1988), "The Dividend-Price Ratio and Expectations of Future Dividends and Discount Factors," Review of Financial Studies, 1, 195-227.

Chen, N.-F., Roll, R. And Ross, S.A. (1986), "Economic Forces and the Stock Market," Journal of Business, 56, 383-403.

Christoffersen, P.F. and Diebold, F.X. (1997), "Optimal Prediction Under Asymmetric Loss," Econometric Theory, 13, 808-817.

Cochrane, J.M. and Piazzesi, M. (2005), "Bond Risk Premia," American Economic Review, 95, forthcoming.

Constantinides, G.M. and Duffie, D. (1996), “Asset Pricing with Heterogeneous Consumers," Journal of Political Economy, 104, 219-240.

Croushore, D. (1997), “The Livingston Survey: Still Useful After All these Years,” Business Review, Federal Reserve Bank of Philadelphia, March, 15-27.

Diebold, F.X. (2004), Elements of Forecasting, third edition. Cincinnati: South-Western.

Fama, E. and French, K. (1988), “Dividend Yields and Expected Stock Returns,” Journal of Financial Economics, 19, 3-29.

Fama, E. and French, K. (1989), "Business Conditions and Expected Returns on Stocks and Bonds," Journal of Financial Economics, 25, 23-49.

Fama, E. and French, K. (1990), "Stock Returns, Expected Returns, and Real Activity,” Journal of Finance, 45, 1089-1108. 
Ferson, W.E. and Harvey, C.R. (1991), "The Variation of Economic Risk Premiums, ”Journal of Political Economy, 99, 1393-1413.

Gultekin, N. B. (1983), "Stock Market Returns and Inflation Forecasts," Journal of Finance, 38, $663-673$.

Guo, H. (2002), "On the Out-of-Sample Predictability of Stock Market Returns," Working Paper 2002-008C, Federal Reserve Bank of St. Louis.

Guo, H. And Savickas, R. (2005), "Idiosyncratic Volatility, Stock Market Volatility, and Expected Stock Returns," Journal of Business and Economic Statistics, forthcoming.

Hamilton, J.D. and Lin, G. (1996), "Stock Market Volatility and the Business Cycle," Journal of Applied Econometrics, 11, 573-593.

Hodrick, R. (1992), "Dividend Yields and Expected Stock Returns: Alternative Procedures for Inference and Measurement," Review of Financial Studies, 5, 357-386.

Leitch, G. and Tanner, J.E. (1991), "Economic Forecast Evaluation: Profits Versus the Conventional Error Measures," American Economic Review, 81, 580-90.

Lettau, M. and Ludvigson, S. (2001a), "Resurrecting the Consumption CAPM: A Cross-Sectional Test When Risk Premia Are Time-Varying," Journal of Political Economy, 109, 1238-1287.

Lettau, M. and Ludvigson, S. (2001b), "Consumption, Aggregate Wealth, and Expected Stock Returns," Journal of Finance, 56, 815-849.

Lettau M. and Ludvigson, S. (2005), "Measuring and Modeling Variation in the Risk-Return Tradeoff," in Y. Ait-Sahalia and L.P Hansen (eds.), Handbook of Financial Econometrics. Amsterdam: North-Holland, forthcoming.

Miller, E. (1977), "Risk, Uncertainty, and Divergence of Opinion," Journal of Finance, 32, 1151-1168.

Shah, H. (1989), "Stock Returns and Anticipated Aggregate Real Activity," Unpublished Ph.D. dissertation, Graduate School of Business, University of Chicago.

Schwert, G.W. (1989), "Why Does Stock Market Volatility Change Over Time?,” Journal of Finance, 44, 1115-1153. 


\section{Table 1}

Summary Statistics for Excess Stock Returns, Livingston Business Conditions Expectations, and Financial Predictors

\begin{tabular}{lccccc}
\hline & $R_{t}$ & $E_{t} g_{t+1, t+2}$ & $D P_{t}$ & $D E F_{t}$ & TERM \\
Mean & 6.35 & 2.54 & 3.32 & 0.96 & 0.79 \\
Median & 9.35 & 2.54 & 3.32 & 0.80 & 0.80 \\
Std. Deviation & 22.30 & 1.51 & 1.11 & 0.44 & 1.03 \\
Skewness & -0.35 & -0.64 & -0.06 & 1.27 & 0.02 \\
Kurtosis & 3.40 & 4.97 & 2.57 & 4.26 & 3.08 \\
& & & & & \\
\hline
\end{tabular}

Notes: In the first column, we report summary statistics for excess returns $\left(R_{t}\right)$ on the value-weighted CRSP index relative to 90-day U.S. Treasuries. In the second column, we report summary statistics for the median two-step-ahead semi-annual growth rate forecasts from the Livingston Survey of Professional Forecasters $\left(E_{t} g_{t+1, t+2}\right)$. In the remaining columns, we report summary statistics for the dividend yield $\left(D P_{t}\right)$, default premium $\left(D E F_{t}\right)$, and the term premium $\left(T E R M_{t}\right)$. The sample period is $t=1952: 1-$ 2003:2, for a sample size of $T=105$ semi-annual observations. We report all variables as annualized percentages. 
Table 2

Regressions of Business Conditions Expectations on Excess Stock Return Predictors

\begin{tabular}{|c|c|c|c|c|}
\hline \multicolumn{5}{|c|}{$\underline{\text { Simple Regressions }}$} \\
\hline$D P_{t}$ & $D E F_{t}$ & $T E R M_{t}$ & $C A Y_{t}$ & $R^{2}$ \\
\hline $\begin{array}{l}-0.28 \\
(0.26)\end{array}$ & -- & -- & -- & $4.2 \%$ \\
\hline-- & $\begin{array}{c}0.40 \\
(0.13)\end{array}$ & -- & -- & $16.2 \%$ \\
\hline-- & -- & $\begin{array}{c}0.20 \\
(0.09)\end{array}$ & -- & $4.1 \%$ \\
\hline-- & -- & -- & $\begin{array}{l}-0.10 \\
(0.10)\end{array}$ & $0.9 \%$ \\
\hline \multicolumn{5}{|c|}{$\underline{\text { Multiple Regressions }}$} \\
\hline $\begin{array}{l}-0.36 \\
(0.19)\end{array}$ & $\begin{array}{c}0.50 \\
(0.14)\end{array}$ & $\begin{array}{c}0.06 \\
(0.09)\end{array}$ & -- & $29.04 \%$ \\
\hline $\begin{array}{l}-0.34 \\
(0.21)\end{array}$ & $\begin{array}{c}0.50 \\
(0.14)\end{array}$ & $\begin{array}{c}0.09 \\
(0.11)\end{array}$ & $\begin{array}{l}-0.06 \\
(0.13)\end{array}$ & $29.32 \%$ \\
\hline
\end{tabular}

Notes: We report OLS estimates of regressions of real GDP growth expectations $\left(E_{t} g_{t+1, t+2}\right)$ on several predictors, 1952:1-2003:2, with Newey-West robust standard errors in parentheses. $D P_{t}, D E F_{t}, T E R M_{t}$ are as defined earlier, and $C A Y_{t}$ is the Lettau-Ludvigson $(2001 \mathrm{a}, \mathrm{b})$ generalized consumption-wealth ratio. We standardize all predictors. See text for details. 
Table 3

Regressions of Excess Stock Returns on

Business Conditions Expectations and Various Additional Predictors

\begin{tabular}{|c|c|c|c|c|c|}
\hline \multicolumn{6}{|c|}{$\underline{\text { Simple Regressions }}$} \\
\hline$E_{t} g_{t+1, t+2}$ & $D P_{t}$ & $D E F_{t}$ & $T E R M_{t}$ & $C A Y_{t}$ & $R^{2}$ \\
\hline $\begin{array}{l}-0.22 \\
(0.08)\end{array}$ & -- & -- & -- & -- & $4.74 \%$ \\
\hline-- & $\begin{array}{c}0.19 \\
(0.10)\end{array}$ & -- & -- & -- & $3.62 \%$ \\
\hline-- & -- & $\begin{array}{l}-0.02 \\
(0.08)\end{array}$ & -- & -- & $0.00 \%$ \\
\hline-- & -- & -- & $\begin{array}{c}0.10 \\
(0.08)\end{array}$ & -- & $0.95 \%$ \\
\hline-- & -- & -- & -- & $\begin{array}{c}0.24 \\
(0.07)\end{array}$ & $5.89 \%$ \\
\hline \multicolumn{6}{|c|}{ Multiple Regressions } \\
\hline-- & $\begin{array}{c}0.25 \\
(0.10)\end{array}$ & $\begin{array}{l}-0.11 \\
(0.07)\end{array}$ & $\begin{array}{c}0.15 \\
(0.07)\end{array}$ & -- & $6.28 \%$ \\
\hline $\begin{array}{l}-0.21 \\
(0.09)\end{array}$ & $\begin{array}{c}0.17 \\
(0.10)\end{array}$ & $\begin{array}{l}-0.01 \\
(0.09)\end{array}$ & $\begin{array}{c}0.17 \\
(0.07)\end{array}$ & -- & $9.41 \%$ \\
\hline-- & $\begin{array}{c}0.18 \\
(0.11)\end{array}$ & $\begin{array}{l}-0.10 \\
(0.07)\end{array}$ & $\begin{array}{l}-0.09 \\
(0.09)\end{array}$ & $\begin{array}{c}0.17 \\
(0.10)\end{array}$ & $8.56 \%$ \\
\hline $\begin{array}{l}-0.20 \\
(0.10)\end{array}$ & $\begin{array}{c}0.12 \\
(0.10)\end{array}$ & $\begin{array}{c}0.00 \\
(0.09)\end{array}$ & $\begin{array}{c}0.11 \\
(0.09)\end{array}$ & $\begin{array}{c}0.16 \\
(0.10)\end{array}$ & $11.35 \%$ \\
\hline $\begin{array}{l}-0.20 \\
(0.08)\end{array}$ & -- & -- & -- & $\begin{array}{c}0.22 \\
(0.08)\end{array}$ & $9.70 \%$ \\
\hline
\end{tabular}

Notes: We report OLS estimates of regressions of excess returns $\left(R_{t+1, t+2}\right)$ on various predictors, 1952:12003:2, with Newey-West robust standard errors in parentheses. We standardize all predictors. See text for details. 


\section{Table 4}

Long-Horizon Regressions of Excess Stock Returns on Business Conditions Expectations and Various Additional Predictors

\begin{tabular}{|c|c|c|c|c|c|c|c|c|c|c|}
\hline \multirow[b]{4}{*}{$D P_{t}$} & \multicolumn{10}{|c|}{ Forecasting Horizon (Months) } \\
\hline & $\beta(6)$ & $\beta(12)$ & $\beta(18)$ & $\beta(24)$ & $\beta(30)$ & $\beta(36)$ & $\beta(42)$ & $\beta(48)$ & $\beta(54)$ & $\beta(60)$ \\
\hline & \multicolumn{10}{|c|}{ Multiple Regression Long-Horizon Betas, Excluding $E_{t}\left(g_{t+1, t+2}\right)$} \\
\hline & 0.180 & 0.346 & 0.501 & 0.646 & 0.783 & 0.911 & 1.030 & 1.140 & 1.250 & 1.350 \\
\hline$D E F_{t}$ & 0.100 & 0.182 & 0.251 & 0.312 & 0.367 & 0.417 & 0.463 & 0.507 & 0.547 & 0.584 \\
\hline$T E R M_{t}$ & 0.090 & 0.148 & 0.186 & 0.211 & 0.228 & 0.240 & 0.249 & 0.257 & 0.264 & 0.270 \\
\hline$C A Y_{t}$ & 0.170 & 0.298 & 0.390 & 0.453 & 0.495 & 0.519 & 0.530 & 0.533 & 0.529 & 0.520 \\
\hline \multirow[t]{2}{*}{$R^{2}(\%)$} & 7.52 & 11.10 & 12.80 & 13.40 & 13.60 & 13.40 & 13.20 & 12.90 & 12.60 & 12.30 \\
\hline & \multicolumn{10}{|c|}{ Multiple Regression Long-Horizon Betas, Including $E_{t}\left(g_{t+1, t+2}\right)$} \\
\hline$E_{t}\left(g_{t+1, t+2}\right)$ & 0.190 & 0.302 & 0.361 & 0.388 & 0.393 & 0.386 & 0.371 & 0.353 & 0.333 & 0.313 \\
\hline$D P_{t}$ & 0.120 & 0.259 & 0.406 & 0.553 & 0.697 & 0.834 & 0.961 & 1.08 & 1.19 & 1.29 \\
\hline$D E F_{t}$ & 0.000 & 0.046 & 0.117 & 0.200 & 0.284 & 0.364 & 0.438 & 0.503 & 0.561 & 0.611 \\
\hline$T E R M_{t}$ & 0.110 & 0.183 & 0.236 & 0.276 & 0.308 & 0.334 & 0.355 & 0.372 & 0.385 & 0.394 \\
\hline$C A Y_{t}$ & 0.160 & 0.268 & 0.340 & 0.386 & 0.416 & 0.434 & 0.444 & 0.450 & 0.452 & 0.452 \\
\hline$R^{2}(\%)$ & 9.90 & 13.00 & 13.80 & 13.70 & 13.40 & 12.90 & 12.40 & 12.00 & 11.60 & 11.20 \\
\hline
\end{tabular}

Notes: We report long-horizon regression coefficients and $R^{2}$ values for horizons ranging from six to sixty months, 1952:1-2003:2. In the top panel we report multiple regression coefficients and $R^{2}$ values for a specification that excludes expected business conditions as a predictor. In the bottom panel we report coefficients and $R^{2}$ values for a specification that includes expected business conditions as a predictor. We standardize all predictors. See text for details. 
Table 5

Hodrick VAR Estimates

\begin{tabular}{|c|c|c|c|c|c|c|c|}
\hline & $R_{t-1, t}$ & $E_{t-1}\left(g_{t, t+1}\right)$ & $D P_{t-1}$ & $D E F_{t-1}$ & $T E R M_{t-1}$ & $C A Y_{t-1}$ & $R^{2}(\%)$ \\
\hline & \multicolumn{7}{|c|}{ VAR(1) Excluding $E_{t}\left(g_{t+1, t+2}\right)$} \\
\hline$R_{t, t+1}$ & 0.00 & 0.00 & $\begin{array}{c}0.18 \\
(0.11)\end{array}$ & $\begin{array}{l}-0.10 \\
(0.07)\end{array}$ & $\begin{array}{c}0.09 \\
(0.09)\end{array}$ & $\begin{array}{c}0.17 \\
(0.10)\end{array}$ & 8.56 \\
\hline$E_{t}\left(g_{t+1, t+2}\right)$ & -- & -- & -- & -- & -- & -- & - \\
\hline$D P_{t}$ & 0.00 & 0.00 & $\begin{array}{c}0.94 \\
(0.04)\end{array}$ & $\begin{array}{l}-0.03 \\
(0.03)\end{array}$ & $\begin{array}{l}-0.06 \\
(0.04)\end{array}$ & $\begin{array}{l}-0.06 \\
(0.03)\end{array}$ & 88.66 \\
\hline$D E F_{t}$ & 0.00 & 0.00 & $\begin{array}{c}0.00 \\
(0.05)\end{array}$ & $\begin{array}{c}0.88 \\
(0.05)\end{array}$ & $\begin{array}{l}-0.21 \\
(0.08)\end{array}$ & $\begin{array}{c}0.01 \\
(0.04)\end{array}$ & 77.44 \\
\hline$T E R M_{t}$ & 0.00 & 0.00 & $\begin{array}{l}-0.13 \\
(0.11)\end{array}$ & $\begin{array}{c}0.15 \\
(0.08)\end{array}$ & $\begin{array}{c}0.57 \\
(0.09)\end{array}$ & $\begin{array}{c}0.19 \\
(0.08)\end{array}$ & 48.06 \\
\hline \multirow[t]{2}{*}{$C A Y_{t}$} & 0.00 & 0.00 & $\begin{array}{c}0.05 \\
(0.08)\end{array}$ & $\begin{array}{c}-0.01 \\
(0.06)\end{array}$ & $\begin{array}{l}-0.02 \\
(0.07)\end{array}$ & $\begin{array}{c}0.72 \\
(0.09)\end{array}$ & 52.75 \\
\hline & \multicolumn{7}{|c|}{$\operatorname{VAR}(1)$ Including $E_{t}\left(g_{t+1, t+2}\right)$} \\
\hline$R_{t, t+1}$ & 0.00 & $\begin{array}{l}-0.19 \\
(0.10)\end{array}$ & $\begin{array}{c}0.12 \\
(0.10)\end{array}$ & $\begin{array}{c}0.00 \\
(0.08)\end{array}$ & $\begin{array}{c}0.11 \\
(0.08)\end{array}$ & $\begin{array}{c}0.16 \\
(0.09)\end{array}$ & 11.35 \\
\hline$E_{t}\left(g_{t+1, t+2}\right)$ & 0.00 & $\begin{array}{c}0.61 \\
(0.06)\end{array}$ & $\begin{array}{l}-0.16 \\
(0.08)\end{array}$ & $\begin{array}{c}0.29 \\
(0.07)\end{array}$ & $\begin{array}{l}-0.12 \\
(0.05)\end{array}$ & $\begin{array}{c}0.10 \\
(0.06)\end{array}$ & 59.41 \\
\hline$D P_{t}$ & 0.00 & $\begin{array}{c}0.06 \\
(0.04)\end{array}$ & $\begin{array}{c}0.96 \\
(0.04)\end{array}$ & $\begin{array}{l}-0.05 \\
(0.04)\end{array}$ & $\begin{array}{l}-0.07 \\
(0.04)\end{array}$ & $\begin{array}{l}-0.05 \\
(0.03)\end{array}$ & 88.92 \\
\hline$D E F_{t}$ & 0.00 & $\begin{array}{l}-0.04 \\
(0.04)\end{array}$ & $\begin{array}{c}-0.01 \\
(0.05)\end{array}$ & $\begin{array}{c}0.91 \\
(0.06)\end{array}$ & $\begin{array}{l}-0.21 \\
(0.08)\end{array}$ & $\begin{array}{c}0.01 \\
(0.04)\end{array}$ & 77.61 \\
\hline$T E R M_{t}$ & 0.00 & $\begin{array}{l}-0.07 \\
(0.07)\end{array}$ & $\begin{array}{c}-0.15 \\
(0.10)\end{array}$ & $\begin{array}{c}0.18 \\
(0.09)\end{array}$ & $\begin{array}{c}0.58 \\
(0.09)\end{array}$ & $\begin{array}{c}0.18 \\
(0.08)\end{array}$ & 48.42 \\
\hline$C A Y_{t}$ & 0.00 & $\begin{array}{c}0.03 \\
(0.07)\end{array}$ & $\begin{array}{c}0.06 \\
(0.09)\end{array}$ & $\begin{array}{l}-0.03 \\
(0.07)\end{array}$ & $\begin{array}{l}-0.03 \\
(0.07)\end{array}$ & $\begin{array}{c}0.71 \\
(0.09)\end{array}$ & 52.83 \\
\hline
\end{tabular}

Notes: We report coefficient estimates and $R^{2}$ values for the Hodrick VAR systems that underlie Table 4 , with Newey-West standard errors in parentheses. We exclude expected business conditions from the VAR in the top panel, and we include them in the bottom panel. We standardize all predictors. See text for details. 
Table 6

Covariance Matrices of Residuals from Hodrick VARs

\begin{tabular}{|c|c|c|c|c|c|c|}
\hline & $R_{t, t+1}$ & $E_{t}\left(g_{t+1, t+2}\right)$ & $D P_{t}$ & $D E F_{t}$ & $T E R M_{t}$ & $C A Y_{t}$ \\
\hline & \multicolumn{6}{|c|}{ VAR(1) Excluding $E_{t}\left(g_{t+1, t+2}\right)$} \\
\hline$R_{t, t+1}$ & 0.92 & - & 0.05 & 0.11 & 0.10 & 0.18 \\
\hline$E_{t}\left(g_{t+1, t+2}\right)$ & -- & -- & -- & -- & -- & - \\
\hline$D P_{t}$ & - & - & 0.11 & 0.04 & 0.00 & 0.10 \\
\hline$D E F_{t}$ & -- & -- & - & 0.22 & 0.10 & 0.07 \\
\hline$T E R M_{t}$ & -- & -- & -- & - & 0.50 & 0.07 \\
\hline \multirow[t]{2}{*}{$C A Y_{t}$} & -- & -- & -- & -- & -- & -- \\
\hline & \multicolumn{6}{|c|}{ VAR(1) Including $E_{t}\left(g_{t+1, t+2}\right)$} \\
\hline$R_{t, t+1}$ & 0.89 & -0.01 & 0.06 & 0.10 & 0.09 & 0.19 \\
\hline$E_{t}\left(g_{t+1, t+2}\right)$ & - & 0.41 & -0.08 & 0.01 & 0.09 & -0.08 \\
\hline$D P_{t}$ & -- & - & 0.10 & 0.05 & 0.00 & 0.10 \\
\hline$D E F_{t}$ & -- & -- & - & 0.22 & 0.10 & 0.07 \\
\hline$T E R M_{t}$ & -- & -- & -- & - & 0.50 & 0.07 \\
\hline$C A Y_{t}$ & -- & -- & -- & -- & -- & 0.47 \\
\hline
\end{tabular}

Notes: We report covariance matrices for the Hodrick VAR systems that underlie Table 4. We exclude expected business conditions from the VAR in the top panel, and we include it in the bottom panel. We standardize all variables. See text for details. 
Table 7

Regressions of Realized Stock Return Volatility on

Business Conditions Expectations and Various Additional Predictors

\begin{tabular}{|c|c|c|c|c|c|}
\hline$E_{t} g_{t+1, t+2}$ & $D P_{t}$ & $D E F_{t}$ & $T E R M_{t}$ & $C A Y_{t}$ & $R^{2}$ \\
\hline \multicolumn{6}{|c|}{ CRSP Value-Weighted Realized Volatility: 1963:1 - 2003:2 } \\
\hline $\begin{array}{c}-0.23 \\
(0.09)\end{array}$ & -- & -- & -- & -- & $5.48 \%$ \\
\hline-- & $\begin{array}{l}-0.32 \\
(0.16)\end{array}$ & -- & -- & -- & $10.18 \%$ \\
\hline-- & -- & $\begin{array}{c}0.11 \\
(0.13)\end{array}$ & -- & -- & $1.15 \%$ \\
\hline-- & -- & -- & $\begin{array}{l}-0.13 \\
(0.14)\end{array}$ & -- & $1.55 \%$ \\
\hline-- & -- & -- & --- & $\begin{array}{l}-0.38 \\
(0.13)\end{array}$ & $14.78 \%$ \\
\hline $\begin{array}{l}-0.42 \\
(0.10)\end{array}$ & $\begin{array}{l}-0.50 \\
(0.15)\end{array}$ & $\begin{array}{c}0.58 \\
(0.15)\end{array}$ & $\begin{array}{l}-0.10 \\
(0.11)\end{array}$ & $\begin{array}{l}-0.32 \\
(0.10)\end{array}$ & $45.44 \%$ \\
\hline \multicolumn{6}{|c|}{ S\&P 500 Realized Volatility: 1951:2 - 2003:2 } \\
\hline $\begin{array}{l}-0.04 \\
(0.10)\end{array}$ & -- & -- & -- & -- & $0.15 \%$ \\
\hline-- & $\begin{array}{l}-0.32 \\
(0.13)\end{array}$ & -- & -- & -- & $9.87 \%$ \\
\hline -- & -- & $\begin{array}{c}0.20 \\
(0.12)\end{array}$ & -- & -- & $4.22 \%$ \\
\hline -- & -- & -- & $\begin{array}{l}-0.04 \\
(0.13)\end{array}$ & -- & $0.19 \%$ \\
\hline-- & -- & -- & -- & $\begin{array}{l}-0.28 \\
(0.11)\end{array}$ & $8.12 \%$ \\
\hline $\begin{array}{c}-0.36 \\
(0.11)\end{array}$ & $\begin{array}{l}-0.50 \\
(0.09)\end{array}$ & $\begin{array}{c}0.51 \\
(0.13)\end{array}$ & $\begin{array}{l}-0.06 \\
(0.10)\end{array}$ & $\begin{array}{l}-0.19 \\
(0.08)\end{array}$ & $33.09 \%$ \\
\hline
\end{tabular}

Notes: We report OLS estimates of regressions of realized stock return volatility, $\sigma_{t+1, t+2}$, on various predictors, 1952:1-2003:2, with Newey-West robust standard errors in parentheses. We standardize all predictors. See text for details. 
Figure 1

Real GDP Growth, Livingston Forecast, and Livingston Forecast Error

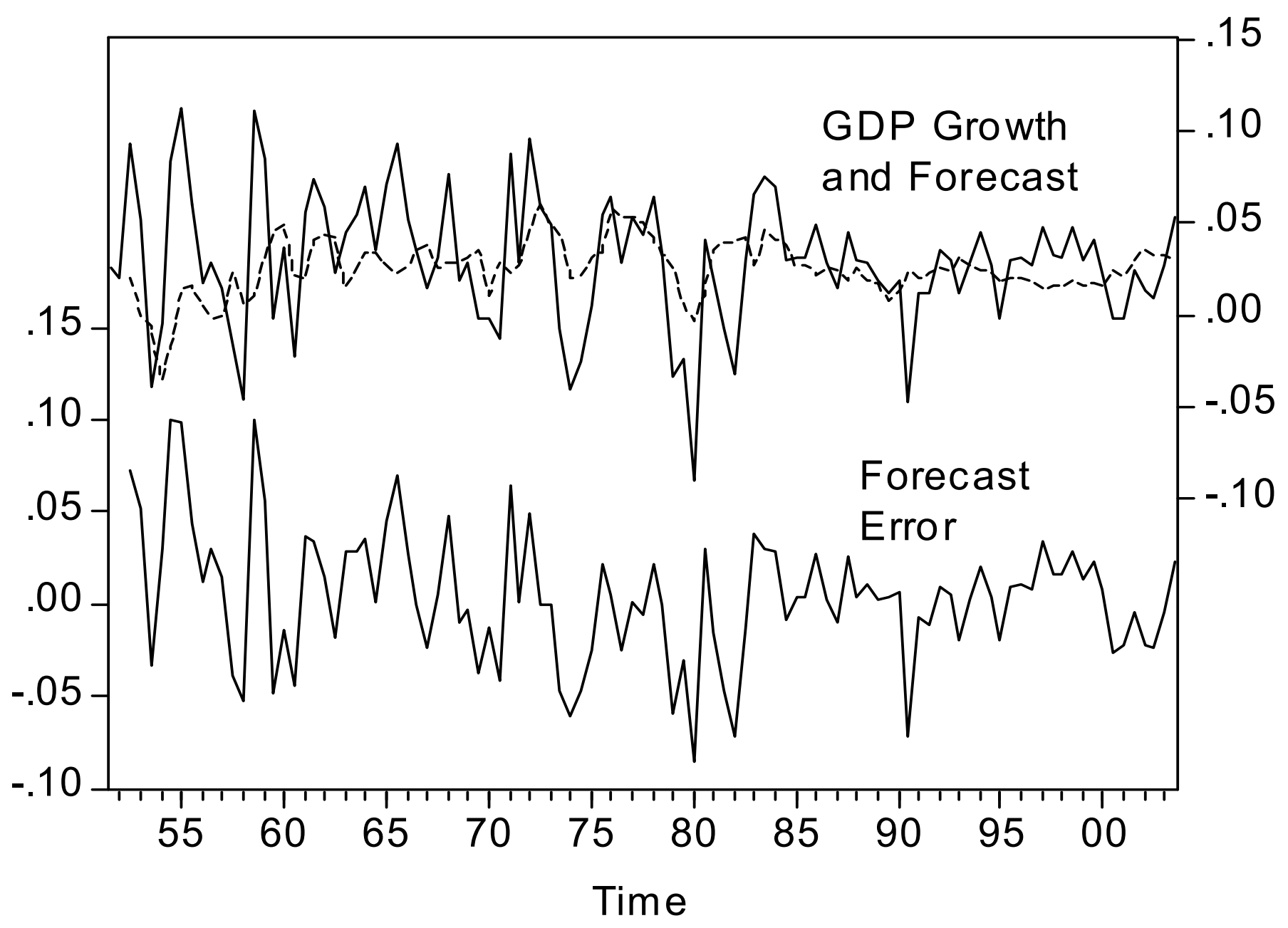

Notes: On the right scale we show U.S. semi-annual real GDP and the corresponding Livingston forecast. On the left scale we show the their difference, the forecast error. See text for details. 
Figure 2

Sample Autocorrelation Function

Two-Step Ahead Real GDP Growth Forecast Errors

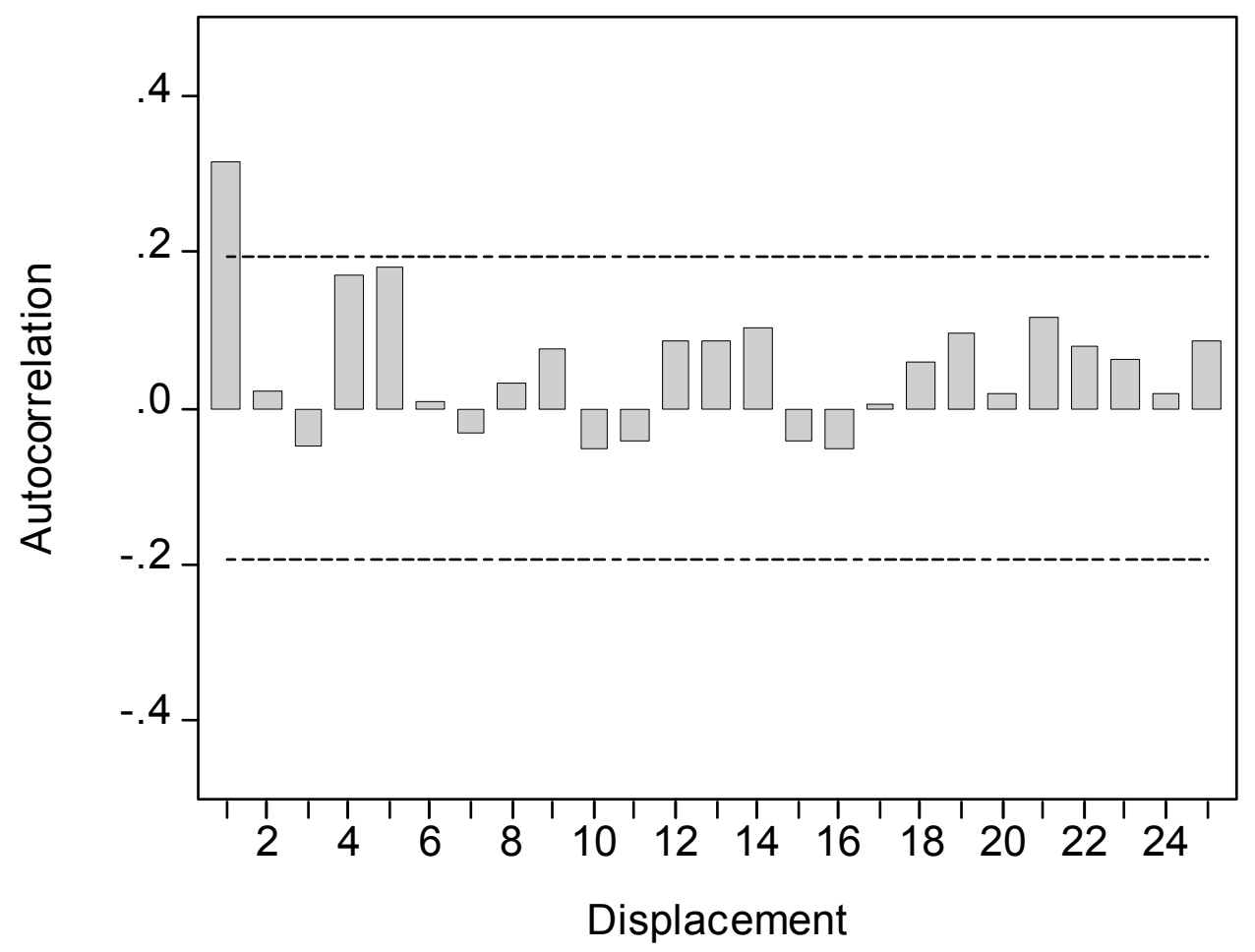

Notes: We report the sample autocorrelation function of two-step-ahead Livingston real GDP growth forecast errors, 1952:1-2003:2, along with approximate ninety-five percent confidence intervals under the null hypothesis of white noise. The forecasts are made semi-annually, so the autocorrelation displacement is measured in units of six months. Hence, for example, a displacement of two corresponds to one year. The Ljung-Box statistic for testing the hypothesis of zero autocorrelations at displacements 2 through 25 is 18.76, which is insignificant at any conventional level. See text for details. 